\title{
cells
}

ISSN 2073-4409

www.mdpi.com/journal/cells

Review

\section{Mechanisms of Activation of Receptor Tyrosine Kinases: Monomers or Dimers}

\author{
Ichiro N. Maruyama \\ Information Processing Biology Unit, Okinawa Institute of Science and Technology Graduate \\ University, 1919-1 Tancha, Onna-son, Kunigami, Okinawa 904-0495, Japan; E-Mail: ichi@oist.jp; \\ Tel.: +81-98-966-8496; Fax: +81-98-966-2890
}

Received: 6 March 2014; in revised form: 10 April 2014 / Accepted: 11 April 2014 /

Published: 21 April 2014

\begin{abstract}
Receptor tyrosine kinases (RTKs) play essential roles in cellular processes, including metabolism, cell-cycle control, survival, proliferation, motility and differentiation. RTKs are all synthesized as single-pass transmembrane proteins and bind polypeptide ligands, mainly growth factors. It has long been thought that all RTKs, except for the insulin receptor (IR) family, are activated by ligand-induced dimerization of the receptors. An increasing number of diverse studies, however, indicate that RTKs, previously thought to exist as monomers, are present as pre-formed, yet inactive, dimers prior to ligand binding. The non-covalently associated dimeric structures are reminiscent of those of the IR family, which has a disulfide-linked dimeric structure. Furthermore, recent progress in structural studies has provided insight into the underpinnings of conformational changes during the activation of RTKs. In this review, I discuss two mutually exclusive models for the mechanisms of activation of the epidermal growth factor receptor, the neurotrophin receptor and IR families, based on these new insights.
\end{abstract}

Keywords: BDNF; cancer; dimerization; EGFR; IGF; ligand; NGF; phosphorylation; rotation/twist; transmembrane signaling; Trk

\section{Introduction}

Phosphorylation of tyrosine is a key post-translational modification of proteins in the propagation of extracellular information to intracellular signal transduction. Receptor tyrosine kinases (RTKs) function through the protein kinase domain located in the intracellular region of each RTK monomer. Ligand 
binding to the extracellular region results in the elevation of the receptor's tyrosine kinase activity and in selective trans-autophosphorylation of tyrosine residues. Some of these sites are involved in maintaining the active conformation of the kinase itself, while others become docking sites for various adaptor/effector scaffold proteins and enzymes.

The human RTK superfamily consists of 58 proteins grouped into 20 sub-families [1]. Apart from the insulin receptor (IR) subfamily, RTKs are all expressed as single protomers that form non-covalently associated dimers. The IR family, consisting of IR, the insulin-like growth factor I-receptor (IGF-IR) and the insulin receptor-related receptor (IRR), is also expressed as a single subunit, but it undergoes processing into form two, $\alpha$ and $\beta$, polypeptide chains that are assembled into a heterotetramer, or an $(\alpha \beta)_{2}$ homodimer, stabilized by disulfide bonds (Figure 1).

Figure 1. Domain organization of RTKs. The following abbreviations are used: L, leucine-rich; CR, cysteine-rich; Ig, immunoglobulin-like; FnIII, fibronectin type III; ID, insert domain. The L1, CR1, L2 and CR2 domains of the ErbB family are alternatively termed Domains I-IV. The ErbB and Trk families are drawn as a monomer, but might be present as non-covalently formed dimers at the cell surface prior to ligand binding (see the main text). Not drawn to scale.

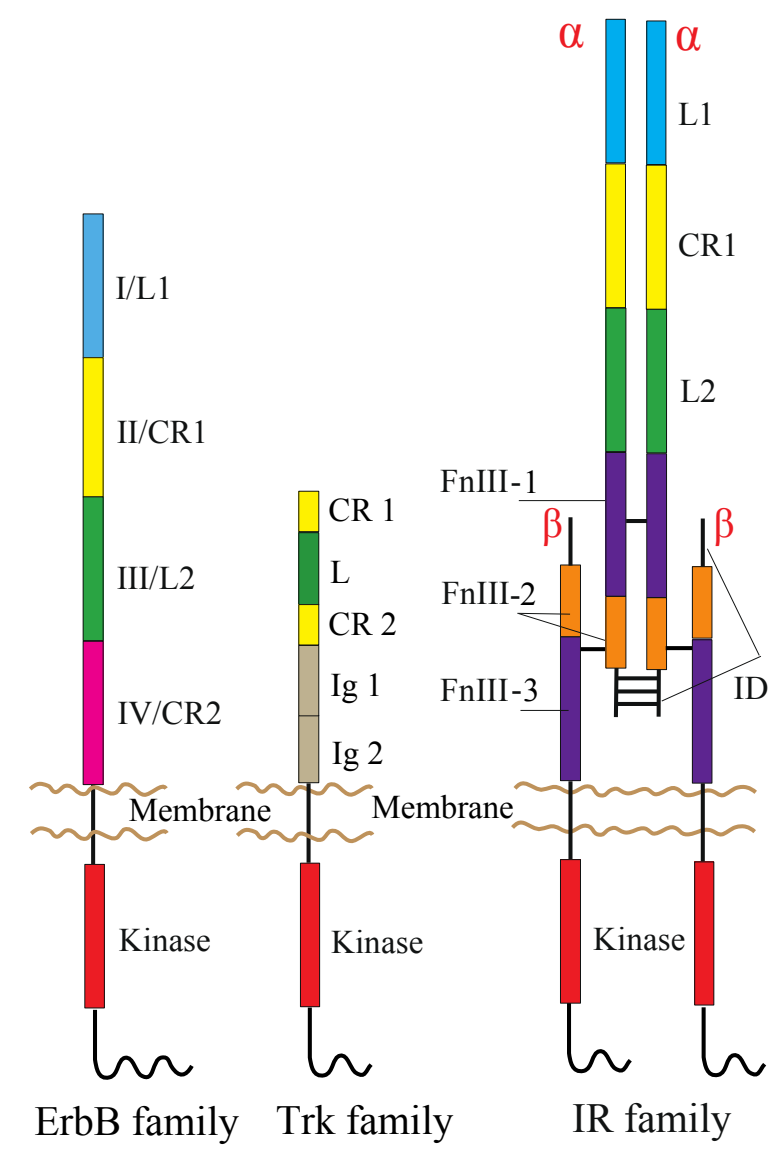

RTK protomers are integral membrane proteins, and their N-terminal extracellular regions are generally composed of various structural modules with multiple, intrachain disulfide bonds and numerous N-linked glycosylation sites. The extracellular region is joined to the intracellular region by a transmembrane (TM) segment. The intracellular region has a tyrosine kinase domain flanked by an intracellular juxtamembrane (JM) region and a C-terminal tail (or extension). The JM and C-terminal tail 
regions differ in size and tyrosine content among family members, and these differences generate and propagate different intracellular signals.

The total number of tyrosine residues found in each intracellular region and the number known to be modified differ significantly between superfamily members, and the distribution of tyrosine residues is quite variable $[2,3]$. For example, the intracellular region of the epidermal growth factor receptor (EGFR), which is a member of the ErbB receptor family (originally named because of the homology to the erythroblastoma viral gene product, v-erbB), has 20 tyrosine residues, 12 of which are known to be phosphorylated, while the intracellular region of TrkA, a member of the neurotrophin (NT) receptor family, contains 11 tyrosine residues, six of which can be phosphorylated. One common modification in the RTK superfamily is the phosphorylation of tyrosine(s) in the activation loop of the kinase domain. An exception to this rule among the commonly studied members of the superfamily is EGFR. It has only a single tyrosine in this position, which is not required for kinase function, although it is phosphorylated upon activation by the epidermal growth factor (EGF) [4]. The role of the activation loop tyrosine(s) is to stabilize the loop in an open conformation, so that both ATP and the substrate peptide can be bound [5].

Other phosphotyrosines provide binding sites for soluble or membrane-anchored proteins that are recruited upon receptor activation [6]. These include scaffolding proteins, which provide additional docking sites for effectors. RTKs activate several pathways linked to cellular phenotypic responses, and these have been extensively studied [7,8]. These include signaling cascades mediated by Ras/Raf/MAP kinase, phosphoinositide-3-kinase (PI3K)/Akt and phospholipase C $\gamma$ (PLC- $\gamma$ ).

It has long been thought that ligand binding activates RTKs by inducing receptor dimerization [9-14]. However, an increasing number of studies demonstrate that RTKs exist as pre-formed, yet inactive, dimers, even in the absence of activating ligand [15-29]. IR and IGF-IR are also expressed as disulfide-linked $(\alpha \beta)_{2}$ homodimers at the cell surface [30]. The ErbB receptor, neurotrophin (NT) receptor and IR families are among the RTKs most extensively studied. Recent crystallographic studies on these receptors with and without bound ligand have led to a clearer understanding of the molecular structures of the RTK active and inactive forms. Negative cooperativity was also observed both in EGFR-EGF and IR-insulin interactions, suggesting that the underlying mechanisms of activation of these receptors by ligand binding may be similar. This review article specifically focuses on the molecular mechanisms of the receptor activation based on the structures elucidated.

\section{RTKs and Their Ligands}

\subsection{ErbB Family}

EGF was discovered in 1962 [31], and its interaction with a cell surface receptor was first characterized in 1975 [32]. The ErbB family consists of EGFR (also known as ErbB1 or HER1), ErbB2 (HER2/Neu), ErbB3 (HER3) and ErbB4 (HER4), and plays important roles in cell growth, differentiation, survival and migration [33,34]. Each ErbB receptor is essential for normal animal development [35]. Aberrant activation of ErbB receptors is implicated in a variety of human cancers [36]. Loss of ErbB4 function results in defects in the heart, nervous system and mammary gland in mice [37,38]. The EGF family binds ErbB receptors, and on the basis of their receptor specificity, they are divided into three groups. The first group includes EGF, transforming growth factor (TGF)- $\alpha$, amphiregulin (AR) and epigen (EPG), which bind specifically to EGFR. The second group includes 
beta-cellulin (BTC), heparin-binding EGF (HB-EGF) and epiregulin (EPR), which exhibit dual specificity, binding both EGFR and ErbB4. The third group, the neuregulins (NRGs), forms two subgroups, depending on whether they bind ErbB3 and ErbB4 (NRG-1 and NRG-2) or only ErbB4 (NRG-3 and NRG-4) [39,40].

ErbB receptors consist of an extracellular ligand-binding region ( $\sim 620$ amino acid residues), a single TM segment ( $\sim 25$ residues), an intracellular JM region ( $\sim 40$ residues), a cytoplasmic kinase domain ( $\sim 270$ residues) and a 220-350 amino acid C-terminal tail that becomes tyrosine phosphorylated following activation and mediates interactions between ErbB receptors and downstream effectors. Mammalian ErbB receptor extracellular regions contain four distinct domains (I-IV) (Figure 1) [12,41,42]. Domains I (also known as L1) and III/L2 are both $\beta$-helix solenoid structures and share $37 \%$ sequence identity with EGFR. These domains are related to the leucine-rich repeat superfamily [43] and are responsible for ligand binding by simultaneously contacting the same bound ligand. Domains II/CR1 and IV/CR2 are both cysteine-rich domains with disulfide bonds similar to those seen in laminin and tumor necrosis factor (TNF) receptor [44]. IR and IGF-IR also share both types of the domains with the ErbB receptors (Figure 1) [30].

In contrast to EGFR, which recognizes a variety of different ligands, ErbB2 lacks a known ligand [45] and acts as a heterodimerization partner for each of the other ErbBs, irrespective of the stimulating ligand [46-49]. ErbB3 has been reported either to have no detectable kinase activity in studies using recombinant protein [50,51] or to have very low activity when immunoprecipitated from cells $[52,53]$. ErbB3 therefore must heterodimerize with other kinase-active ErbB receptors to signal, and ErbB2 appears to be the preferred dimerization partner for ErbB3 [47]. In the ErbB2/ErbB3 heterodimer, both ErbB2 and ErbB3 become phosphorylated [47]. As phosphorylation occurs in trans, it is clear that the kinase-active ErbB2 could phosphorylate the C-terminal tail of ErbB3. However, it is difficult to explain how ErbB2 could be phosphorylated by the kinase-inactive ErbB3 in the context of an ErbB2/ErbB3 heterodimer. Indeed, it has recently been shown that ErbB3 possesses sufficient kinase activity to robustly trans-autophosphorylate its own intracellular region [54]. In addition, phosphorylation of ErbB2 may also occur within ErbB2/ErbB3 tetramers, in which the ErbB2 from one dimer phosphorylates the ErbB2 in the other dimer [55].

\subsection{NT Receptor Family}

The pioneering discovery of the nerve growth factor (NGF) [56] set the stage for the discovery of other NTs. In mammals, NGF, brain-derived neurotrophic factor (BDNF), NT-3, NT-4/5, NT-6 and NT-7 act through the NT receptor family, which consists of three tropomyosin-related kinase receptors (TrkA, TrkB and TrkC) and $\mathrm{p} 75^{\mathrm{TNR}}$, which is a member of the TNF receptor superfamily and does not have kinase activity. TrkA preferentially interacts with NGF, NT-7, and to a lesser extent, NT-6 [57,58]. TrkB interacts with BDNF and NT-4/5 [59,60], and TrkC is specific for NT-3 [61-63]. NT-3 can also interact with TrkA and TrkB with low affinity, and all the NTs can bind $\mathrm{p} 75^{\mathrm{NTR}}$ with low affinity [64-66]. NTs are initially synthesized in the endoplasmic reticulum as prepro-NTs, and cleavage of the signal peptide of prepro-NTs converts these into pro-NTs. In the trans-Golgi network and in secretory vesicles, pro-NTs dimerize and are proteolytically processed by proprotein convertase enzymes to their mature forms before their release from the cell [67]. In the extracellular space, pro-NTs may be cleaved by plasmin, and the secreted, mature forms of NTs exist in solution as dimers $[67,68]$. 
Trk receptor kinases play crucial roles in the development and maintenance of the central and peripheral nervous systems, in the preventing or reversing of neuronal degeneration and in the enhancement of synaptic plasticity [69]. TrkA is widely expressed in sympathetic, trigeminal and dorsal root ganglia and in cholinergic neurons of the basal forebrain and striatum [58,70,71]. TrkB is found throughout the central and peripheral nervous systems, and TrkC is widely expressed in mammalian neural tissues [61,72,73]. Activation of Trk initiates downstream signaling cascades mediated by Ras/Raf/MAP kinase, PI3K/Akt and PLC- $\gamma$ [74-76]. Aberrant activation of Trk kinases is often observed in human cancers. Constitutively active TrkA fusions occur in some thyroid cancers and colon carcinomas [77]. TrkB and its ligand, BDNF, are highly expressed in biologically unfavorable neuroblastomas, and TrkB expression is associated with drug resistance and the expression of angiogenic factors [78]. Fusion of the TrkC gene with the ETV6 transcription factor gene has been described in oncogenic carcinomas and acute myelogenous leukemias [79].

TrkA, TrkB and TrkC share significant sequence homology and a conserved domain organization comprising, from the $\mathrm{N}$-terminus to $\mathrm{C}$-terminus, an extracellular region, a TM segment and an intracellular region containing the kinase domain (Figure 1). The extracellular region consists of five domains, a leucine-rich region (L) flanked by two cysteine-rich regions (CR1 and CR2) and two immunoglobulin-like domains (Ig1 and Ig2) [80]. The kinase domains of TrkA, TrkB and TrkC share between $71.9 \%$ and $78.3 \%$ sequence identity, TrkB and TrkC being the closest homologues [81]. Studies on TrkB and TrkC have shown that the Ig2 domain is sufficient for the binding of ligands and is responsible for their binding specificity [82-84]. The crystal structures of Ig2 of TrkA, TrkB and TrkC, as well as TrkA Ig2 in complex with NGF have been solved $[85,86]$.

\subsection{IR Family}

Insulin is a peptide hormone discovered in 1921 [87], and its ability to promote glucose uptake into tissues was demonstrated in 1949 [88]. Insulin, IGF-I and IGF-II share a common three-dimensional architecture and bind IR and IGF-IR with differing affinities. In contrast to the critical role of insulin in metabolic control, the IGFs act via IGF-IR to promote cell proliferation, survival and differentiation. IGFs are essential for normal growth and development, and perturbation of IGF-I expression is associated with acromegaly [89] or short stature [90]. Disruption of IGF-II imprinting during development is associated with overgrowth in Beckwith-Wiedemann syndrome, whereas reduced paternal allele expression results in growth retardation in Silver-Russell syndrome [91]. Furthermore, IGFs acting via the IGF-IR play a major role in promoting cancer cell growth and survival [92].

Specific cell-surface receptors for insulin were identified in 1971 [93]. The IR exists in two isoforms, IR-A and IR-B, which arise by alternative splicing of exon 11 [94,95]. The IR-B isoform, which differs from IR-A by the presence of a 12-residue segment (encoded by exon 11) inserted between IR-A Residues 716 and 717, three residues before the C-terminus of the $\alpha$-chain, binds insulin with high affinity. The IR-A isoform can also binds IGF-II, albeit with a six-fold lower affinity [96,97]. These receptors are disulfide-linked homodimers, which also function as heterodimer hybrids, since IR::IGF-IR hybrids have been detected in all tissues that express both receptors $[98,99]$. While stimulation of IR with insulin primarily modulates cellular metabolism, the main function of activated IGF-IR is to promote cell proliferation and survival [100,101]. None of the known IR or IGF-IR ligands can activate IRR [102,103], which is primarily expressed in the kidneys, stomach and pancreas [104,105]. Recently, 
IRR has been shown to be activated by alkaline media both in vitro and in vivo at $\mathrm{pH}>7.9$, indicating its role as an alkaline sensor molecule in the kidney [106]. A triple Ir Igflr Irr gene knockout fails to develop the male phenotype, while all single and double knockouts do, suggesting that IRR can substitute for the other receptors in mice and is required for male sexual differentiation [107].

Each receptor extracellular region consists of, from the N-terminus to the C-terminus, a leucine-rich repeat domain (L1), a cysteine-rich region (CR), a second leucine-rich repeat domain (L2) and three fibronectin type III domains (FnIII-1, FnIII-2 and FnIII-3), the second of which contains the large ( 120 residues) insert domain (ID) (Figure 1) [108,109]. The ID contains a furin cleavage site that generates the $\alpha$-chain and $\beta$-chain of the mature receptor monomer. The intracellular region of each IR family monomer contains a tyrosine kinase domain flanked by two regulatory regions, the JM region and the C-terminal tail, that contain the phosphotyrosine binding sites for effector signaling molecules [110]. In particular, the JM region is involved in docking IR substrates, IRS1-4 [111] and Shc, as well as in receptor internalization [112-114]. Activation of IR and IGF-IR leads to signaling via two main pathways. Following the activation of the tyrosine kinase domain, receptors undergo autophosphorylation, which promotes the binding of effector molecules. These proteins then lead to the activation of PI3K/Akt and the extracellular signal-regulated kinase (ERK/MAPK) cascades [113].

\section{Are TRKs Monomeric or Dimeric Prior to Ligand Binding?}

\subsection{ErbB Family}

EGFR is one of the first receptors for which ligand-induced dimerization was proposed as a primary event in transmembrane signaling, mainly based on biochemical data $[9,115,116]$. In this 'dimerization model', the ErbB family receptor is thought to exist as a monomer at the cell surface prior to ligand binding, and ligand binding induces dimerization, as a result of which intracellular kinase domains become closer and trans-phosphorylate each other. Furthermore, recently, it has been suggested that the receptor monomers are at equilibrium with the receptor dimers [8,117]. A limited population of receptor dimers ( $<10 \%$ of total receptors) exists with quaternary structures of their extracellular and cytoplasmic regions in configurations that are compatible with trans-autophosphorylation (active dimer). Ligand binding to the extracellular region stabilizes the formation of active dimers and, consequently, induces kinase stimulation [8].

More recently, an increasing number of studies have demonstrated that prior to ligand binding, ErbB receptors exist as dimers at the cell surface [15-25,28,29]. By chemical cross-linking, it was found that $>80 \%$ of EGFR is dimeric in the absence of bound ligand [15]. Hetero-Förster resonance energy transfer (FRET) [16,18,20], fluorescence correlation spectroscopy (FCS) [20,21,25] and homo-FRET [23] analyses further demonstrated that EGFR and ErbB2 are present as dimers at physiological expression levels at the surface of living cells. Fluorescent protein fragment complementation indicates that the majority, if not all, of all the members of the ErbB family exists as dimers in living cells [22]. This is consistent with the results from reversible firefly luciferase enzyme fragment complementation analysis that all the EGFR and ErbB3 receptors exist as dimers in living cells, since fluorescence intensity was never increased by the addition of EGF to the cell culture [24,28,29]. Single molecule observation using total internal reflection fluorescence (TIRF) microscopy using oblique illumination also indicates the existence of dimers in living cells [19]. Depending on the methods used, dimer-to-monomer ratios vary 
from 40\%-100\%. Considering inefficient chemical crosslinking [118] and inefficient folding of fluorescent proteins [119-121], these ratios are likely to be, if at all, underestimated. The existence of significant numbers of pre-formed dimers is supported by evidence that autophosphorylation of the receptors can be enhanced by inhibitors of protein tyrosine phosphatases or by receptor overexpression, even in the absence of bound ligand [8,122].

However, this has recently been challenged. Brightness analysis of ErbB receptors using fluorescence microscopy suggested that at lower expression levels than $2 \times 10^{5}$ molecules per cell, EGFR is monomeric [123]. Since the brightness of fluorescent protein tags differs in cytosol and close to the cell membrane [20], the existence of monomers should be re-evaluated based on the brightness of reference monomeric molecules in the vicinity of the membrane. Furthermore, a recent study that used two-color pulsed-interleaved excitation fluorescence cross-correlation spectroscopy, in which a pair of lasers alternatively excited GFP and mCherry with subnanosecond pulses, to analyze if EGFR expressed at very low levels in COS-7 cells, found that it is present as a monomer at the surface of living cells [14]. Since COS-7 expresses low levels of endogenous EGFR [124], however, the result should be re-evaluated using cells that do not express endogenous EGFR.

\subsection{NT Receptor Family}

It is also under debate whether the Trk receptors are monomeric, dimeric or oligomeric prior to ligand binding. NT has been proposed to induce Trk dimerization [125,126], whereas there is evidence that Trk receptors exist as pre-formed dimers [26,27] or oligomers [127] at the cell surface prior to NT binding. In the absence of bound NTs, p75 ${ }^{\mathrm{NTR}}$ has a disulfide-linked dimeric structure through a highly conserved cysteine in its TM segment [128]. A recent biophysical analysis based on the diffusivity of receptors at the surface of the membrane suggests that $>70 \%$ and $\sim 20 \%$ of TrkA molecules are monomeric and dimeric or oligomeric, respectively [129]. It is, however, necessary to correlate the diffusivities with monomeric, dimeric and oligomeric structures by other means, since TrkA may exist as a pre-formed dimer with the highest diffusion rate, and a small fraction of the receptors may be present as tetramers or oligomers, possibly near coated pits after autophosphorylation, due to the receptor's overexpression. Although functional interactions between Trk receptors and $\mathrm{p} 75^{\mathrm{NTR}}$ are apparent, the nature of their physical associations and the formation of complexes with NTs remain areas of ongoing debate and study [130-133].

\subsection{IR Family}

Unlike other RTKs, IR and IGF-IR are covalently disulfide-linked $(\alpha \beta)_{2}$ dimers made of two extracellular $\alpha$-subunits that contain the ligand-binding domains and two transmembrane $\beta$-subunits that contain the intracellular kinase domain [134-136]. There is evidence for the existence of a covalently disulfide-linked $(\alpha \beta)_{2}$ hybrid dimeric receptor (IR::IGF-IR), which is composed of an IR $\alpha \beta$ hemireceptor and an IGF-IR $\alpha \beta$ hemireceptor [137-140]. Cross-talk between insulin, IGFs and their receptors appears to be relatively common in many tissues and organs. Like insulin, IGF-I also exhibits important metabolic effects, for example in vivo infusion of recombinant IGF-I leads to an acute decrease in circulating glucose values [141]. 


\section{Mechanisms of RTK Activation}

\subsection{ErbB Family}

The crystal structures of the extracellular region of unliganded ErbB receptors [142-145] and of ligand-bound EGFR [146,147] have revealed large conformational changes that are crucial for ligand-induced dimerization of the receptor extracellular regions. An intramolecular tether is observed in the extracellular region of unliganded EGFR, ErbB3 and ErbB4. The 'dimerization arm' of II/CR1 is buried and interacts with loops at the C-terminal end of IV/CR2 to form an 'auto-inhibited' conformation (Figure 2) [142-144]. In the ligand-bound form, the I-II/L1-CR1 unit is rotated and moved away from the IV/CR2 domain, so as to be stabilized in an extended configuration in which the II/CR1 and IV/CR2 loops of the EGFR are both exposed and positioned to interact with a second partner to form the 2:2 back-to-back complex (Figure 2) [146,147]. Each ligand molecule is clamped between the I/L1 and III/L2 domains of the same EGFR molecule. The ligand-free 'tethered' configuration and the ligand-bound 'extended' configuration are mutually exclusive. In addition, parts of Domain IV/CR2 are thought to come close (or into direct contact) at the dimer interface based on both biochemical studies [148] and modeled structures [143]. In a dimer of EGFR extracellular regions, all intermolecular contacts are mediated by the receptor [146,147], making EGFR unique among RTKs with known ligand-bound structures. In all other such cases, the ligand contributes directly to the dimer interface [7].

Figure 2. Schematic representations of the structures of the extracellular regions of the ErbB family. EGFR, ErbB3 and ErbB4 adopt the tethered conformation in the absence of ligand, while ErbB2 adopts an extended, or untethered, conformation that resembles the ligand-activated, dimerization-competent EGFR protomer in the ligand-bound form of the EGFR dimer, shown at the right. The 'dimerization arm' and 'tethering arm' are shown by an asterisk and an open triangle, respectively. Ligands are shown in red. Domains I-IV correspond to the domains shown in Figure 1. Not drawn to scale.

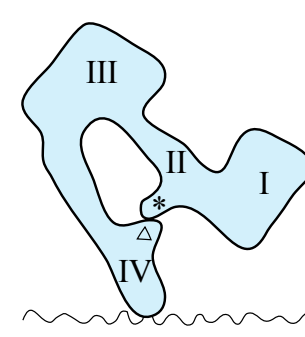

EGFR

ErbB3

ErbB4

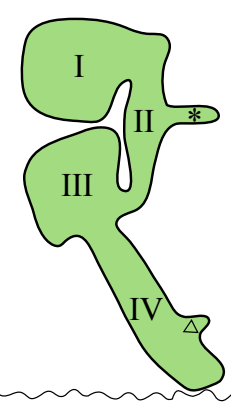

ErbB2

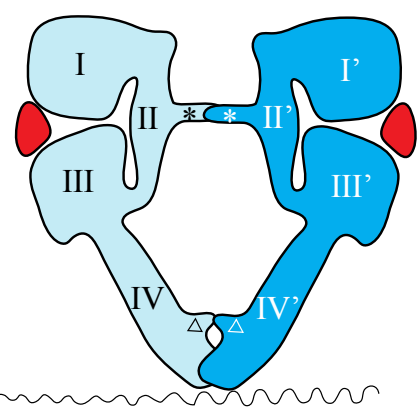

EGFR

Mutations that weaken or eliminate the II-IV/CR1-CR2 interaction indicate that untethering alone is insufficient for EGFR activation and that ligand binding is essential for the correct positioning of the two receptors to achieve full kinase activation [149]. The extracellular region of ErbB2, which does not have a known ligand, exists in the 'extended' configuration (Figure 2) [150,151], poised to interact with the 
ligand-bound form of the extracellular region of other EGFR family members. This suggests that ErbB2 can function as a heterodimer partner for the other ErbB family members, as described above.

The recent structures of the EGFR kinase in an apparently inactive, symmetric dimer [152-154] and an active, asymmetric dimer [153] provide insight into the structural underpinnings of these conformational changes. In the inactive, symmetric conformation, the helix $\alpha \mathrm{C}$ of the $\mathrm{N}$-terminal lobe of the kinase domain is rotated outward with respect to its conformation in the active state, and the centrally located activation loop is tightly packed inside the active site in a way that blocks the binding of peptide substrates. Upon activation, the $\alpha \mathrm{C}$ helix rotates toward the active site, resulting in an open conformation of the activation loop that is compatible with the binding of substrate peptides $[152,153,155]$. In the active, asymmetric kinase domain dimer, the C-terminal lobe of the 'activator/donor' kinase contacts the $\mathrm{N}$-terminal lobe of the adjacent 'receiver/acceptor' kinase and promotes conformational changes that activate the 'receiver/acceptor' kinase. Thus, ligand binding is likely to dissociate the inactive, symmetric kinase dimer, resulting in the active, asymmetric kinase dimer, in which the 'activator/donor' kinase activates the adjacent 'receiver/acceptor' kinase. This type of interaction is reminiscent of the activating interaction between cyclins and the N-terminal lobes of cyclin-dependent kinases and was suggested to be conserved in other ErbBs, based on their amino acid sequence similarity $[153,156]$. In the active, asymmetric dimer, the N-terminal portions of the intracellular JM region (referred to as JM-A) of the receiver/acceptor and the activator/donor kinases are likely to interact, and the residues important for this interaction are conserved among the four ErbB family members. The C-terminal portion of the JM region (referred to as JM-B or JMAD) of the 'receiver/acceptor' kinase interacts with the C-terminal lobe of the 'activator/donor' kinase domain in a latching interaction $[152,157]$.

Two mutually exclusive 'dimerization' and 'rotation/twist' models for ligand-induced activation of the ErbB receptors have been proposed, based on the monomeric and dimeric structures of inactive ErbBs prior to ligand binding, respectively (Figure 3). Both of the models are consistent with the crystallographic structures with and without bound ligand described above. In the 'dimerization' model $[11,14,115]$, the receptor is proposed to exist as a monomer at the cell surface prior to ligand binding. Ligand binding to the extracellular I-III/L1-L2 domains of the tethered form releases the interaction between II/CR1 and IV/CR2 and exposes the 'dimerization arm' of the II/CR1 domain in its extended configuration. This exposed 'dimerization arm' interacts with the exposed 'dimerization arm' of the other receptor to form a dimer, in which two intracellular kinase domains assume the asymmetric active structure. In contrast, the 'rotation/twist' model [15,22] predicts that the receptor exists as a dimer at the cell surface, in which the extracellular regions have the tethered structure and the intracellular kinase domains have the symmetric, inactive dimeric structure. Upon ligand binding to untethered extracellular regions of the receptor dimer, two exposed 'dimerization arms' interact with each other to form extended configurations. This conformational change, from untethered to extended, induces the rotation/twist of TM segments [15] that rearrange the inactive, symmetric kinase domain dimers to take the active, asymmetric conformation. In the asymmetric kinase dimers, the 'activator/donor' kinase activates the adjacent 'receiver/acceptor' kinase, as described above. 
Figure 3. Models for ligand-induced activation of the ErbB family. (A) 'Dimerization' model. (B) 'Rotation/twist' model. For the explanation of the models, see the main text. Not drawn to scale.

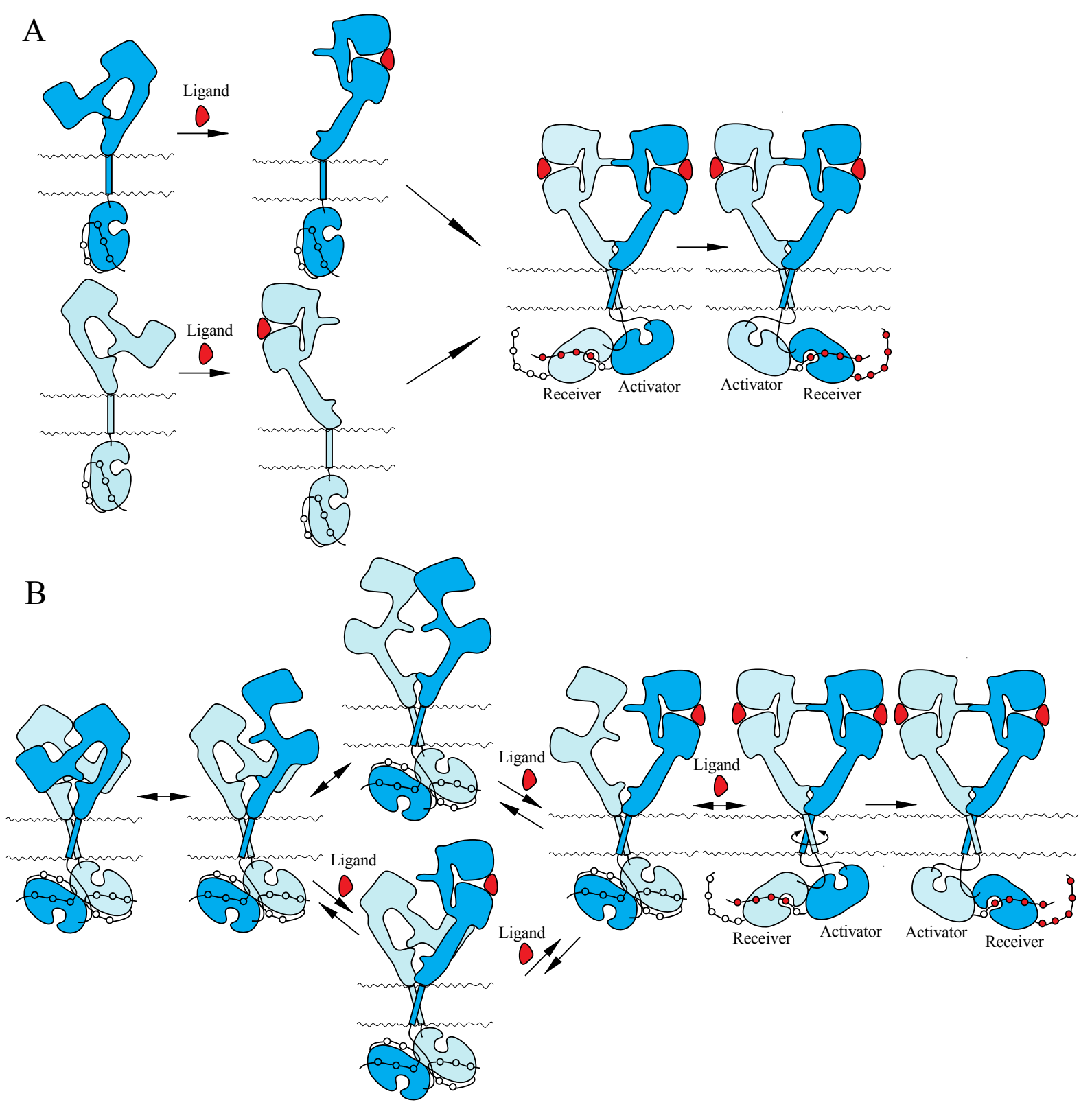

\subsection{NT Receptor Family}

Early work on PC12 cells provided the initial evidence that NGF mediated its effects by binding to the TrkA receptor, inducing receptor dimerization and autophosphorylation $[58,70,158]$. Because NT ligands exist in solution as stable, non-covalently associated homodimers [159-161], it is thought that a single NGF dimer acts as a bridge to induce the dimerization of two TrkA monomers [162]. This model was supported by the crystal structure of NGF bound to the ligand-binding immunoglobulin domains of TrkA, which has been shown to have a symmetric 2:2 stoichiometry in the complex [86]. This 'dimerization' model suggests that the high local membrane density of Trk receptor proteins may promote spontaneous activation in the absence of NTs under scenarios of overexpression. Recent studies using chemical crosslinking and reversible firefly luciferase fragment complementation assay, however, 
demonstrate that all the TrkA and TrkB receptors exist as pre-formed, yet inactive, dimers at the surface of living cells [26,27]. These results are consistent with the recent crystal structures of inactive, symmetric kinase domain dimers of TrkA and $\operatorname{TrkC}[81,163]$. Therefore, the ligand-induced dimerization model needs to be re-evaluated.

NT-dependent $\mathrm{p} 75^{\mathrm{NTR}}$ activation involves the association of an NT dimer with repeats of a 40-amino acid, cysteine-rich domain of the two extracellular regions of a p $75^{\mathrm{NTR}}$ dimer [130]. As described above, an unusual feature of the $\mathrm{p} 75^{\mathrm{NTR}}$ structure is the existence of a disulfide-linked $\mathrm{p} 75^{\mathrm{NTR}}$ dimer, formed through cysteine residues within its TM segment. This disulfide linkage is required for effective NT-dependent signaling by $\mathrm{p} 75^{\mathrm{NTR}}$ [128]. Recent studies propose a model in which NT binding causes the two extracellular regions of $\mathrm{p} 75^{\mathrm{NTR}}$ dimers to move closer together, forcing the intracellular regions to splay apart in a snail-tong-like, or scissors-like, motion centered on the disulfide bond and permitting the association of the intracellular regions with the signaling adapter proteins, NRIF and TRAF6 [128,164].

\subsection{IR Family}

IR receptors are present as disulfide-linked $(\alpha \beta)_{2}$ homodimers at the cell surface, as described above. Ligand binding to the extracellular region of the receptors induces conformational changes in their structures and activates their intrinsic tyrosine kinase activity. Two scenarios can be envisioned for the inactive state prior to ligand binding. First, the intracellular kinase domains are spatially separated and, thus, cannot undergo trans-phosphorylation. Second, the kinase domains are arranged to prevent trans-phosphorylation (perhaps as an inactive dimer). A partially activating point mutation (Y984A) in the intracellular JM region of IR [165] is more consistent with the latter mechanism [166]. In the crystal structure of the IR kinase domain [167], the unphosphorylated activation loop adopts an autoinhibitory configuration in which the second of the three activation-loop tyrosines is bound in the kinase active site through hydrogen bonding to residues in the catalytic loop. This inhibitory conformation is observed in IGF-IR, as well [168]. Upon IR trans-phosphorylation, the phosphorylated activation loop is stabilized in a conformation that is optimized to bind substrates for catalysis [166]. Despite the recent structural elucidation of the insulin-bound IR extracellular region [169], the mechanism of insulin-initiated transmembrane signaling remains largely elusive.

\section{Cooperative Ligand Binding}

Scatchard analysis of the binding of EGFR and IR with EGF and insulin, respectively, yields concave-up or curvilinear plots that indicate the presence of two classes of binding sites. It has long been thought that EGFR exists as both monomers and dimers at the cell surface, with low and high affinity, respectively $[11,170]$. However, the heterogeneity in EGF-binding affinities has recently been proposed to arise from negative cooperativity in the interaction between EGF and its receptor [171,172]. Analysis of insulin binding to IR also reveals curvilinear (concave-up) Scatchard plots, which has also been explained by a negative cooperative interaction between insulin and IR [173].

\subsection{ErbB Family}

EGF binding to cell-surface receptors was first reported over 30 years ago [174,175]. EGF binding has been characterized by either negative cooperativity or heterogeneity of sites and has traditionally 
been interpreted to suggest the existence of two classes of EGF-binding site at the cell surface $[170,175]$. In this analysis, a high-affinity class accounts for $\sim 10 \%$ of receptors with a dissociation constant $\left(K_{\mathrm{d}}\right)$ of $\sim 10^{-10} \mathrm{M}$ and a low-affinity class with a $K_{\mathrm{d}}$ of $\sim 10^{-9} \mathrm{M}$. It is generally believed that the mitogenic actions of EGF are mediated through the high affinity site [176-179]. The nature of the high- and low-affinity sites is still under debate. EGFR phosphorylation at Thr-654 by protein kinase $\mathrm{C}$ reduces the number of high-affinity EGF-binding sites at the cell surface [180], and deletions from the intracellular region of EGFR are likely to prevent the receptor from forming high-affinity sites [181,182]. However, models demonstrating that the high- and low-affinity sites represent EGFR dimers and monomers, respectively, cannot explain the observed binding characteristics. All such models lead to positive cooperativity with concave-down, not concave-up, Scatchard plots [183]. Biophysical analysis of the isolated extracellular region of human EGFR suggested a positive cooperative interaction between EGF and EGFR [184]. The concave-up Scatchard plots observed at the cell surface could only be explained by invoking an 'external site' that independently stabilizes a fraction of receptor molecules in a high-affinity dimeric state $[181,185,186]$. Heterogeneities in receptor density at the cell surface have been employed by others to explain the observed concave-up Scatchard plot [187]. A requirement for negative cooperativity is that EGFR dimers bind one EGF. Binding of a second EGF must occur with lower affinity than the first. Indeed, a recent study of ${ }^{125}$ I-labelled EGF binding to EGFR at the cell surface $[171,172]$ yielded a model characterized by negative cooperativity that had previously been predicted [183]. The crystal structures of the Drosophila EGFR extracellular region suggest negative cooperativity between EGFR and its ligand [188]. Consistent with this, a recent study suggests that a single ligand may be sufficient to activate EGFR dimers [189]. In contrast, there is evidence showing that binding of two EGF molecules is required for EGFR autophosphorylation [190]. An electron microscopy study of nearly a full-length EGFR bound with EGF also showed no evidence of negative cooperativity [191].

There is evidence that interaction between the 'tethering' arms (Residues 561-585 of Domain IV/CR2 in the extracellular region; Figure 2) in the EGFR dimer is essential for negative cooperativity in EGF binding [192]. Breaking the disulfide bond between Cys-558 and Cys-567 of the tethering arm of the Domain IV/CR2 in the extracellular region of EGFR through double alanine replacements or deleting the loop entirely decreased negative cooperativity in EGF binding. Deletion of the loop between Cys-571 and Cys-593 of the tethering arm also abrogates negative cooperativity. These results demonstrate that the tethering arm plays an important role in supporting cooperativity in ligand binding and suggest that the tethering arm contributes to intersubunit interactions within the EGFR dimer prior to ligand binding [192].

The intracellular JM region is divided into two segments, termed JM-A, which includes Residues 645-664, and JM-B/JMAD, which includes Resides 665-682, as described above [152,157]. In the crystal structure of the asymmetric dimer of the intracellular region [157], the JM-A segment appears as a helix oriented away from the kinase domains. Furthermore, NMR and mutational analyses of the JM-A segment suggest that this region may form an anti-parallel helical dimer that functions as a clasp to stabilize the asymmetric dimer [152]. Binding of EGF to its receptor is negatively cooperative [171], and the intracellular JM region is required for this allosteric regulation of ligand binding [172]. Internal deletion of the JM-A segment results in the complete loss of all cooperativity in EGF binding [193]. This suggests that JM-A plays a role in the ligand binding properties of the receptor. In the anti-parallel helical dimer of JM-A in the receptor dimer, Glu-663 and Glu-666 are predicted to be involved in interhelical salt bridges that would stabilize the helical dimer. When these ionic interactions 
are removed by mutation, negative cooperativity in EGF binding to EGFR is abrogated [193]. This again suggests that the proposed helical dimer could contribute to negative cooperativity in EGFR. It has long been recognized that phosphorylation of EGFR at Thr-654 leads to a decrease in the affinity of EGF and a loss of EGF-stimulated receptor autophosphorylation [174,175,194]. Phorbol 12-myristate 13-aceatte (PMA)-induced phosphorylation of Thr-654 leads to the complete loss of cooperativity [193]. These results suggest that the JM-A segment represents an important structural component underlying negative cooperativity in EGFR.

\subsection{NT Receptor Family}

Steady-state binding experiments have demonstrated that TrkA has a single binding site for NGF with a $K_{\mathrm{d}}$ of $10^{-9} \mathrm{M}$, a value reflecting low affinity binding, similar to the $\mathrm{p} 75^{\mathrm{NTR}}$ interaction $[58,71]$. This is consistent with the crystallographic structure of two Ig2 domains bound with an NGF dimer [86]. Reconstitution experiments by transient transfection into heterologous cells indicate that high-affinity NGF binding requires co-expression of both $\mathrm{p} 75^{\mathrm{NTR}}$ and TrkA [71,195-197], while $\mathrm{p} 75^{\mathrm{NTR}}$ has a negative effect on TrkB tyrosine autophosphorylation in response to BDNF and NT-4/5 and no effect on TrkB and TrkC activation in response to NT-3 [198]. Over the past two decades, a number of mechanistic models of the functional interactions between $\mathrm{p} 75^{\mathrm{NTR}}$ and TrkA have been proposed [199], which include the formation of a classic 1:1 heterodimer with higher affinity than the individual receptors [71,195], and the ligand-passing model in which $\mathrm{p} 75^{\mathrm{NTR}}$ first binds to NGF before releasing the ligand for TrkA to bind [195,199]. However, these models are inconsistent with the observation that the extracellular ligand-binding domain of $\mathrm{p} 75^{\mathrm{NTR}}$ is not required to create high-affinity NGF binding sites [200]. A recent observation also indicates that the $\mathrm{p} 75^{\mathrm{NTR}}$ intracellular domain fragment, but not the full-length p $75^{\text {NTR }}$, enhances NGF binding to TrkA [133]. These observations suggest that small intracellular peptides of $\mathrm{p} 75^{\mathrm{NTR}}$ interact with intracellular regions of TrkA (perhaps in its dimeric form) to induce conformational changes of the receptor's intracellular region. This may, in turn, induce conformational changes of the extracellular regions that lead to a high affinity conformation of the receptor (dimer) for NGF binding.

\subsection{IR Family}

IR family receptors are pre-formed disulfide-linked $(\alpha \beta)_{2}$ dimers, and trans-phosphorylation occurs within the dimer rather than via higher-order oligomerization [201]. Analysis of insulin binding to IR reveals concave-up (curvilinear) Scatchard plots and negative cooperativity, indicating that only one insulin molecule binds to one $(\alpha \beta)_{2}$ dimer $[173,202]$. Each monomer in the IR dimer is thought to contain two separate ligand-binding regions, Site 1 and Site 2, on one monomer, and Site 1' and Site 2', on the other. Binding of ligand to Site 1 of one monomer is then followed by 'cross-linking' of the bound ligand to the second site (Site 2') of the alternate monomer [203]. Within this model, negative cooperativity results from subsequent ligand binding to the alternate Site 1'/Site 2 pair and concomitant release of ligand at the initial Site 1/Site 2' pocket. This model suggests that a pair of ligands cannot cross-link Site 1/Site 2' and cross-link Site 1'/Site 2 simultaneously [204]. This model has recently been refined by assuming that the formation of the high-affinity cross-link is enabled by harmonic oscillation of the receptor $[205,206]$. 
In support of this hypothesis, purified $\alpha \beta$ monomers prepared by the mild reduction of interhalf disulfide (Class I disulfide) bonds show only low affinity binding with a stoichiometry of one insulin per $\alpha \beta$ monomer, whereas purified $(\alpha \beta)_{2}$ dimers exhibit negative cooperativity and only one high affinity insulin-binding site [207,208]. Double probe analysis using two different insulin analogues showed that only one analogue could bind to the receptor with high affinity at a time [209,210]. Unlike the full-length receptors, soluble extracellular regions show only low-affinity ligand binding, unless they are C-terminally tethered by transmembrane anchors, Fc domains or leucine zippers [211]. In addition to negative cooperativity, positive cooperativity for IR binding has also been reported at low insulin concentrations [212]. That is, receptor occupancy seems to enhance the binding of insulin to its receptor at low ligand levels.

\section{Concluding Remarks}

It is now clear that ErbB receptors are allosteric enzymes, indicating that they are likely to dimerize in the absence of ligand. Indeed, a wide variety of studies demonstrate the ErbB receptors exist as dimers at the surface of living cells prior to ligand binding [15,17-25,28,29]. NT receptors also exist as covalently-linked $\mathrm{p} 75^{\mathrm{NTR}}$ or non-covalently-linked pre-formed TrkA and TrkB dimers prior to ligand binding [26,27,128]. These dimeric structures are reminiscent of IR, which is a covalently-linked pre-formed dimer that nonetheless requires insulin binding for activity [203]. Cooperativity long observed in the interaction between insulin and IR is now also observed in the EGF-EGFR interaction [171]. These observations suggest that EGFR and IR may be activated by similar mechanisms. Indeed, an early study on signaling by IR::EGFR chimeras argued that the regulatory mechanisms of these two receptor classes are closely related [213]. Thus, RTKs may be activated by cognate ligand binding through similar mechanisms.

\section{Acknowledgments}

The author is thankful to Charlotte Fournier, Thorsten Wohland and members of the Maruyama lab for their helpful comments on the manuscript.

\section{Conflicts of Interest}

The author declare no conflict of interest.

\section{References}

1. Blume-Jensen, P.; Hunter, T. Oncogenic kinase signaling. Nature 2001, 411, 355-365.

2. Blagoev, B.; Ong, S.E.; Kratchmarova, I.; Mann, M. Temporal analysis of phosphotyrosine-dependent signaling networks by quantitative proteomics. Nat. Biotechnol. 2004, 22, 1139-1145.

3. Bradshaw, R.A.; Chalkley, R.J.; Biarc, J.; Burlingame, A.L. Receptor tyrosine kinase signaling mechanisms: Devolving TrkA responses with phosphoproteomics. Adv. Biol. Regul. 2013, 53, 87-96. 
4. Gotoh, N.; Tojo, A.; Hino, M.; Yazaki, Y.; Shibuya, M. A highly conserved tyrosine residue at codon 845 within the kinase domain is not required for the transforming activity of human epidermal growth factor receptor. Biochem. Biophys. Res. Commun. 1992, 186, 768-774.

5. Hubbard, S.R.; Till, J.H. Protein tyrosine kinase structure and function. Annu. Rev. Biochem. 2000, 69, 373-398.

6. Pawson, T. Regulation and targets of receptor tyrosine kinases. Eur. J. Cancer 2002, 38, S3-S10.

7. Lemmon, M.A.; Schlessinger, J. Cell signaling by receptor tyrosine kinases. Cell 2010, 141, $1117-1134$.

8. Schlessinger, J. Cell signaling by receptor tyrosine kinases. Cell 2000, 103, 211-225.

9. Ullrich, A.; Schlessinger, J. Signal transduction by receptors with tyrosine kinase activity. Cell 1990, 61, 203-212.

10. Heldin, C.H. Dimerization of cell surface receptors in signal transduction. Cell 1995, 80, 213-223.

11. Schlessinger, J. Ligand-induced, receptor-mediated dimerization and activation of EGF receptor. Cell 2002, 110, 669-672.

12. Burgess, A.W.; Cho, H.S.; Eigenbrot, C.; Ferguson, K.M.; Garrett, T.P.; Leahy, D.J.; Lemmon, M.A.; Sliwkowski, M.X.; Ward, C.W.; Yokoyama, S. An open-and-shut case? Recent insights into the activation of EGF/ErbB receptors. Mol. Cell 2003, 12, 541-552.

13. Bublil, E.M.; Yarden, Y. The EGF receptor family: Spearheading a merger of signaling and therapeutics. Curr. Opin. Cell Biol. 2007, 19, 124-134.

14. Endres, N.F.; Das, R.; Smith, A.W.; Arkhipov, A.; Kovacs, E.; Huang, Y.; Pelton, J.G.; Shan, Y.; Shaw, D.E.; Wemmer, D.E.; et al. Conformational coupling across the plasma membrane in activation of the EGF receptor. Cell 2013, 152, 543-556.

15. Moriki, T.; Maruyama, H.; Maruyama, I.N. Activation of preformed EGF receptor dimers by ligand-induced rotation of the transmembrane domain. J. Mol. Biol. 2001, 311, 1011-1026.

16. Martin-Fernandez, M.; Clarke, D.T.; Tobin, M.J.; Jones, S.V.; Jones, G.R. Preformed oligomeric epidermal growth factor receptors undergo an ectodomain structure change during signaling. Biophys. J. 2002, 82, 2415-2427.

17. Yu, X.; Sharma, K.D.; Takahashi, T.; Iwamoto, R.; Mekada, E. Ligand-independent dimer formation of epidermal growth factor receptor (EGFR) is a step separable from ligand-induced EGFR signaling. Mol. Biol. Cell 2002, 13, 2547-2557.

18. Clayton, A.H.; Walker, F.; Orchard, S.G.; Henderson, C.; Fuchs, D.; Rothacker, J.; Nice, E.C.; Burgess, A.W. Ligand-induced dimer-tetramer transition during the activation of the cell surface epidermal growth factor receptor-A multidimensional microscopy analysis. J. Biol. Chem. 2005, 280, 30392-30399.

19. Teramura, Y.; Ichinose, J.; Takagi, H.; Nishida, K.; Yanagida, T.; Sako, Y. Single-molecule analysis of epidermal growth factor binding on the surface of living cells. EMBO J. 2006, 25, 4215-4222.

20. Liu, P.; Sudhaharan, T.; Koh, R.M.; Hwang, L.C.; Ahmed, S.; Maruyama, I.N.; Wohland, T. Investigation of the dimerization of proteins from the epidermal growth factor receptor family by single wavelength fluorescence cross-correlation spectroscopy. Biophys. J. 2007, 93, 684-698.

21. Saffarian, S.; Li, Y.; Elson, E.L.; Pike, L.J. Oligomerization of the EGF receptor investigated by live cell fluorescence intensity distribution analysis. Biophys. J. 2007, 93, 1021-1031. 
22. Tao, R.H.; Maruyama, I.N. All EGF(ErbB) receptors have preformed homo- and heterodimeric structures in living cells. J. Cell Sci. 2008, 121, 3207-3217.

23. Bader, A.N.; Hofman, E.G.; Voortman, J.; En Henegouwen, P.M.; Gerritsen, H.C. Homo-FRET imaging enables quantification of protein cluster sizes with subcellular resolution. Biophys. J. 2009, 97, 2613-2622.

24. Yang, K.S.; Ilagan, M.X.; Piwnica-Worms, D.; Pike, L.J. Luciferase fragment complementation imaging of conformational changes in the epidermal growth factor receptor. J. Biol. Chem. 2009, 284, 7474-7482.

25. Ma, X.; Ahmed, S.; Wohland, T. EGFR activation monitored by SW-FCCS in live cells. Front. Biosci. (Elite Ed.) 2011, 3, 22-32.

26. Shen, J.; Maruyama, I.N. Nerve growth factor receptor TrkA exists as a preformed, yet inactive, dimer in living cells. FEBS Lett. 2011, 585, 295-299.

27. Shen, J.; Maruyama, I.N. Brain-derived neurotrophic factor receptor TrkB exists as a preformed dimer in living cells. J. Mol. Signal. 2012, 7, 2.

28. Macdonald-Obermann, J.L.; Piwnica-Worms, D.; Pike, L.J. Mechanics of EGF receptor/ErbB2 kinase activation revealed by luciferase fragment complementation imaging. Proc. Natl. Acad. Sci. USA 2012, 109, 137-142.

29. Macdonald-Obermann, J.L.; Adak, S.; Landgraf, R.; Piwnica-Worms, D.; Pike, L.J. Dynamic analysis of the epidermal growth factor (EGF) receptor-ErbB2-ErbB3 protein network by luciferase fragment complementation imaging. J. Biol. Chem. 2013, 288, 30773-30784.

30. Ward, C.W.; Lawrence, M.C.; Streltsov, V.A.; Adams, T.E.; McKern, N.M. The insulin and EGF receptor structures: New insights into ligand-induced receptor activation. Trends Biochem. Sci. 2007, 32, 129-137.

31. Cohen, S. Isolation of a mouse submaxillary gland protein accelerating incisor eruption and eyelid opening in the new-born animal. J. Biol. Chem. 1962, 237, 1555-1562.

32. Carpenter, G.; Lembach, K.J.; Morrison, M.M.; Cohen, S. Characterization of the binding of 125-I-labeled epidermal growth factor to human fibroblasts. J. Biol. Chem. 1975, 250, 4297-4304.

33. Holbro, T.; Hynes, N.E. ErbB receptors: Directing key signaling networks throughout life. Annu. Rev. Pharmacol. Toxicol. 2004, 44, 195-217.

34. Yarden, Y.; Sliwkowski, M.X. Untangling the ErbB signaling network. Nat. Rev. Mol. Cell Biol. 2001, 2, 127-137.

35. Olayioye, M.A.; Neve, R.M.; Lane, H.A.; Hynes, N.E. The ErbB signaling network: Receptor heterodimerization in development and cancer. EMBO J. 2000, 19, 3159-3167.

36. Hynes, N.E.; MacDonald, G. ErbB receptors and signaling pathways in cancer. Curr. Opin. Cell Biol. 2009, 21, 177-184.

37. Gassmann, M.; Casagranda, F.; Orioli, D.; Simon, H.; Lai, C.; Klein, R.; Lemke, G. Aberrant neural and cardiac development in mice lacking the ErbB4 neuregulin receptor. Nature 1995, 378, 390-394.

38. Tidcombe, H.; Jackson-Fisher, A.; Mathers, K.; Stern, D.F.; Gassmann, M.; Golding, J.P. Neural and mammary gland defects in ErbB4 knockout mice genetically rescued from embryonic lethality. Proc. Natl. Acad. Sci. USA 2003, 100, 8281-8286. 
39. Hynes, N.E.; Lane, H.A. ERBB receptors and cancer: The complexity of targeted inhibitors. Nat. Rev. Cancer 2005, 5, 341-354.

40. Harris, R.C.; Chung, E.; Coffey, R.J. EGF receptor ligands. Exp. Cell Res. 2003, 284, 2-13.

41. Lemmon, M.A. Ligand-induced ErbB receptor dimerization. Exp. Cell Res. 2009, 315, 638-648.

42. Jorissen, R.N.; Walker, F.; Pouliot, N.; Garrett, T.P.; Ward, C.W.; Burgess, A.W. Epidermal growth factor receptor: Mechanisms of activation and signaling. Exp. Cell Res. 2003, 284, 31-53.

43. Ward, C.W.; Garrett, T.P.J. The relationship between the L1 and L2 domains of the insulin and epidermal growth factor receptors and leucine-rich repeat modules. BMC Bioinform. 2001, 2, 4.

44. Ward, C.W.; Garrett, T.P.J.; McKern, N.M.; Lou, M.; Cosgrove, L.J.; Sparrow, L.G.; Frenkel, M.J.; Hoyne, P.A.; Elleman, T.C.; Adams, T.E.; et al. The three dimensional structure of the type I insulin-like growth factor receptor. Mol. Pathol. 2001, 54, 125-132.

45. Wilson, K.J.; Gilmore, J.L.; Foley, J.; Lemmon, M.A.; Riese, D.J., 2nd. Functional selectivity of EGF family peptide growth factors: Implications for cancer. Pharmacol. Ther. 2009, 122, 1-8.

46. Karunagaran, D.; Tzahar, E.; Beerli, R.R.; Chen, X.; Graus-Porta, D.; Ratzkin, B.J.; Seger, R.; Hynes, N.E; Yarden, Y. ErbB-2 is a common auxiliary subunit of NDF and EGF receptors: Implications for breast cancer. EMBO J. 1996, 15, 254-264.

47. Tzahar, E.; Waterman, H.; Chen, X.; Levkowitz, G.; Karunagaran, D.; Lavi, S.; Ratzkin, B.J.; Yarden, Y. A hierarchical network of interreceptor interactions determines signal transduction by Neu differentiation factor/neuregulin and epidermal growth factor. Mol. Cell. Biol. 1996, 16, 5276-5287.

48. Graus-Porta, D.; Beerli, R.R.; Daly, J.M.; Hynes, N.E. ErbB-2, the preferred heterodimerization partner of all ErbB receptors, is a mediator of lateral signaling. EMBO J. 1997, 16, 1647-1655.

49. Klapper, L.N.; Glathe, S.; Vaisman, N.; Hynes, N.E.; Andrews, G.C.; Sela, M.; Yarden, Y. The ErbB-2/HER2 oncoprotein of human carcinomas may function solely as a shared coreceptor for multiple stroma-derived growth factors. Proc. Natl. Acad. Sci. USA 1999, 96, 4995-5000.

50. Guy, P.M.; Platko, J.V.; Cantley, L.C.; Cerione, R.A.; Carraway, K.L., 3rd. Insect cell-expressed p180erbB3 possesses an impaired tyrosine kinase activity. Proc. Natl. Acad. Sci. USA 1994, 91, 8132-8136.

51. Sierke, S.L.; Cheng, K.; Kim, H.H.; Koland, J.G. Biochemical characterization of the protein tyrosine kinase homology domain of the ErbB3 (HER3) receptor protein. Biochem. J. 1997, 322, 757-763.

52. Prigent, S.A.; Gullick, W.J. Identification of c-erbB-3 binding sites for phosphatidylinositol 3'-kinase and SHC using an EGF receptor/c-erbB-3 chimera. EMBO J. 1994, 13, 2831-2841.

53. Wallasch, C.; Weiss, F.U.; Niederfellner, G.; Jallal, B.; Issing, W.; Ullrich, A. Heregulin-dependent regulation of HER2/neu oncogenic signaling by heterodimerization with HER3. EMBO J. 1995, 14, 4267-4275.

54. Shi, F.; Telesco, S.E.; Liu, Y.; Radhakrishnan, R.; Lemmon, M.A. ErbB3/HER3 intracellular domain is competent to bind ATP and catalyze autophosphorylation. Proc. Natl. Acad. Sci. USA 2010, 107, 7692-7697.

55. Zhang, Q.; Park, E.; Kani, K.; Landgraf, R. Functional isolation of activated and unilaterally phosphorylated heterodimers of ERBB2 and ERBB3 as scaffolds in ligand-dependent signaling. Proc. Natl. Acad. Sci. USA 2012, 109, 13237-13242. 
56. Levi-Montalcini, R.; Angeletti, P.U. Essential role of the nerve growth factor in the survival and maintenance of dissociated sensory and sympathetic embryonic nerve cells in vitro. Dev. Biol. 1963, 7, 653-659.

57. Lai, K.O.; Fu, W.Y.; Ip, F.C.; Ip, N.Y. Cloning and expression of a novel neurotrophin, NT-7, from carp. Mol. Cell. Neurosci. 1998, 11, 64-76.

58. Kaplan, D.R.; Hempstead, B.L.; Martin-Zanca, D.; Chao, M.V.; Parada, L.F. The trk proto-oncogene product: A signal transducing receptor for nerve growth factor. Science 1991, 252, 554-558.

59. Ip, N.Y.; Ibanez, C.F.; Nye, S.H.; McClain, J.; Jones, P.F.; Gies, D.R.; Belluscio, L.; Le Beau, M.M.; Espinosa, R., 3rd; Squinto, S.P.; et al. Mammalian neurotrophin-4: Structure, chromosomal localization, tissue distribution, and receptor specificity. Proc. Natl. Acad. Sci. USA 1992, 89, 3060-3064.

60. Klein, R.; Nanduri, V.; Jing, S.A.; Lamballe, F.; Tapley, P.; Bryant, S.; Cordon-Cardo, C.; Jones, K.R.; Reichardt, L.F.; Barbacid, M. The trkB tyrosine protein kinase is a receptor for brain-derived neurotrophic factor and neurotrophin-3. Cell 1991, 66, 395-403.

61. Lamballe, F.; Klein, R.; Barbacid, M. trkC, a new member of the trk family of tyrosine protein kinases, is a receptor for neurotrophin-3. Cell 1991, 66, 967-979.

62. Soppet, D.; Escandon, E.; Maragos, J.; Middlemas, D.S.; Reid, S.W.; Blair, J.; Burton, L.E.; Stanton, B.R.; Kaplan, D.R.; Hunter, T.; et al. The neurotrophic factors brain-derived neurotrophic factor and neurotrophin-3 are ligands for the trkB tyrosine kinase receptor. Cell 1991, 65, 895-903.

63. Squinto, S.P.; Stitt, T.N.; Aldrich, T.H.; Davis, S.; Bianco, S.M.; Radziejewski, C.; Glass, D.J.; Masiakowski, P.; Furth, M.E.; Valenzuela, D.M.; et al. trkB encodes a functional receptor for brain-derived neurotrophic factor and nejurotrophin-3 but not nerve growth factor. Cell 1991, 65, 885-893.

64. Rodriguez-Tebar, A.; Dechant, G.; Gotz, R.; Barde, Y.A. Binding of neurotrophin-3 to its neuronal receptors and interactions with nerve growth factor and brain-derived neurotrophic factor. $E M B O$ J. 1992, 11, 917-922.

65. Barbacid, M. The Trk family of neurotrophin receptors. J. Neurobiol. 1994, 25, 1386-1403.

66. Huang, E.J.; Reichardt, L.F. Trk receptors: Roles in neuronal signal transduction. Annu. Rev. Biochem. 2003, 72, 609-642.

67. Lessmann, V.; Brigadski, T. Mechanisms, locations, and kinetics of synaptic BDNF secretion: An update. Neurosci. Res. 2009, 65, 11-22.

68. Lessmann, V.; Gottmann, K.; Malcangio, M. Neurotrophin secretion: Current facts and future prospects. Prog. Neurobiol. 2003, 69, 341-374.

69. Chao, M.V.; Rajagopal, R.; Lee, F.S. Neurotrophin signalling in health and disease. Clin. Sci. (Lond.) 2006, 110, 167-173.

70. Kaplan, D.R.; Martin-Zanca, D.; Parada, L.F. Tyrosine phosphorylation and tyrosine kinase activity of the trk proto-oncogene product induced by NGF. Nature 1991, 350, 158-160.

71. Hempstead, B.L.; Martin-Zanca, D.; Kaplan, D.R.; Parada, L.F.; Chao, M.V. High-affinity NGF binding requires coexpression of the trk proto-oncogene and the low-affinity NGF receptor. Nature 1991, 350, 678-683. 
72. Klein, R.; Lamballe, F.; Bryant, S.; Barbacid, M. The trkB tyrosine protein kinase is a receptor for neurotrophin-4. Neuron 1992, 8, 947-956.

73. Cordon-Cardo, C.; Tapley, P.; Jing, S.Q.; Nanduri, V.; O’Rourke, E.; Lambelle, F.; Kovary, K.; Klein, R.; Jones, K.R.; Reichardt, L.F.; et al. The trk tyrosine protein kinase mediates the mitogenic properties of nerve growth factor and neurotrophin-3. Cell 1991, 66, 173-183.

74. Simi, A.; Ibáñez, C.F. Assembly and activation of neurotrophic factor receptor complexes. Dev. Neurobiol. 2010, 70, 323-331.

75. Chao, M.V. Neurotrophins and their receptors: A convergence point for many signaling pathways. Nat. Rev. Neurosci. 2003, 4, 299-309.

76. Kaplan, D.R.; Miller, F.D. Neurotrophin signal transduction in the nervous system. Curr. Opin. Neurobiol. 2000, 10, 381-391.

77. Nakagawara, A. Trk receptor tyrosine kinases: A bridge between cancer and neural development. Cancer Lett. 2001, 169, 107-114.

78. Brodeur, G.M.; Minturn, J.E.; Ho, R.; Simpson, A.M.; Lyer, R.; Varela, C.R.; Light, J.E.; Kolla, V.; Evans, A.E. Trk receptor expression and inhibition in neuroblastomas. Clin. Cancer Res. 2009, 15, 3244-3250.

79. Tognon, C.; Knezevich, S.R.; Huntsman, D.; Roskelley, C.D.; Melnyk, N.; Mathers, J.A.; Becker, L.; Carneiro, F.; MacPherson, N.; Horsman, D.; et al. Expression of the ETV6-NTRK3 gene fusion as a primary event in human secretory breast carcinoma. Cancer Cell 2002, 2, 367-376.

80. Schneider, R.; Schweiger, M. A novel modular mosaic of cell adhesion motifs in the extracellular domains of the neurogenic trk and trkB tyrosine kinase receptors. Oncogene 1991, 6, 1807-1811.

81. Bertrand, T.; Kothe, M.; Liu, J.; Dupuy, A.; Rak, A.; Berne, P.F.; Davis, S.; Gladysheva, T.; Valtre, C.; et al. The crystal structures of TrkA and TrkB suggest key regions for achieving selective inhibition. J. Mol. Biol. 2012, 423, 439-453.

82. Holden, P.H.; Asopa, V.; Robertson, A.G.; Clarke, A.R.; Tyler, S.; Bennett, G.S.; Brain, S.D.; Wilcock, G.K.; Allen, S.J.; Smith, S.K.; et al. Immunogloblin-like domains define the nerve growth factor binding site of the TrkA receptor. Nat. Biotechnol. 1997, 15, 668-672.

83. Perez, P.; Coll, P.M.; Hempstead, B.L.; Martin-Zanca, D.; Chao, M.V. NGF binding to the trk tyrosine kinase receptor requires the extracellular immunoglobulin-like domains. Mol. Cell. Neurosci. 1995, 6, 97-105.

84. Urfer, R.; Tsoulfas, P.; O’Connell, L.; Presta, L.G. Specificity determinants in neurotrophin-3 and design of nerve growth factor-based trkC agonists by changing central $\beta$-strand bundle residues of their neurotrophin-3 analogs. Biochemistry 1997, 36, 4775-4781.

85. Ultsch, M.H.; Wiesmann, C.; Simmons, L.C.; Henrich, J.; Yang, M.; Reilly, D.; Bass, S.H.; de Vos, A.M. Crystal structures of the neurotrophin-binding domain of TrkA, TrkB and TrkC. J. Mol. Biol. 1999, 290, 149-159.

86. Wiesmann, C.; Ultsch, M.H.; Bass, S.H.; de Vos, A.M. Crystal structure of nerve growth factor in complex with the ligand-binding domain of the TrkA receptor. Nature 1999, 401, 184-188.

87. Steiner, D.F. Insulin Today. Diabetes 1976, 26, 322-340.

88. Levine, R.; Goldstein, M.; Klein, S.; Huddlestun, B. The action of insulin on the distribution of galactose in eviscerated nephrectomized dogs. J. Biol. Chem. 1949, 179, 985-986. 
89. Renehan, A.G.; Brennan, B.M. Acromegaly, growth hormone and cancer risk. Best Pract. Res. Clin. Endocrinol. Metab. 2008, 22, 639-657.

90. Walenkamp, M.J.E.; Wit, J.M. Genetic disorders in the growth hormone - insulin-like growth factor-I axis. Horm. Res. 2006, 66, 221-230.

91. Gicquel, C.; Le Bouc, Y. Hormonal regulation of fetal growth. Horm. Res. 2006, 65, $28-33$.

92. Gallagher, E.J.; LeRoith, D. The proliferating role of insulin and insulin-like growth factors in cancer. Trends Endocrinol. Metab. 2010, 21, 610-618.

93. Freychet, P.; Roth, J.; Neville, D.M., Jr. Insulin receptors in the liver: Specific binding of $\left[{ }^{125} \mathrm{I}\right]$ insulin to the plasma membrane and its relation to insulin bioactivity. Proc. Natl. Acad. Sci. USA 1971, 68, 1833-1837.

94. Denley, A.; Wallace, J.C.; Cosgrove, L.J.; Forbes, B.E. The insulin receptor isoform exon 11- (IR-A) in cancer and other diseases: A review. Horm. Metab. Res. 2003, 35, 778-785.

95. Belfiore, A.; Frasca, F.; Pandini, G.; Sciacca, L.; Vigneri, R. Insulin receptor isoforms and insulin receptor/insulin-like growth factor receptor hybrids in physiology and disease. Endocr. Rev. 2009, 30, 586-623.

96. Frasca, F.; Pandini, G.; Scalia, P.; Sciacca, L.; Mineo, R.; Costantino, A.; Goldfine, I.D.; Belfiore, A.; Vigneri, R. Insulin receptor isoform A, a newly recognized, high-affinity insulin-like growth factor II receptor in fetal and cancer cells. Mol. Cell. Biol. 1999, 19, 3278-3288.

97. Denley, A.; Bonython, E.R.; Booker, G.W.; Cosgrove, L.J.; Forbes, B.E.; Ward, C.W.; Wallace, J.C. Structural determinants for high-affinity binding of insulin-like growth factor II to insulin receptor (IR)-A, the exon 11 minus isoform of the IR. Mol. Endocrinol. 2004, 18, 2502-2512.

98. Slaaby, R.; Schaffer, L.; Lautrup-Larsen, I.; Andersen, A.S.; Shaw, A.C.; Mathiasen, I.S.; Brandt, J. Hybrid receptors formed by insulin receptor (IR) and insulin-like growth factor I receptor (IGF-IR) have low insulin and high IGF-1 affinity irrespective of the IR splice variant. J. Biol. Chem. 2006, 281, 25869-25874.

99. Benyoucef, S.; Surinya, K.H.; Hadaschik, D.; Siddle, K. Characterization of insulin/IGF hybrid receptors: Contributions of the insulin receptor L2 and Fn1 domains and the alternatively spliced exon 11 sequence to ligand binding and receptor activation. Biochem. J. 2007, 403, 603-613.

100. De Meyts, P. Insulin and insulin-like growth factors: The paradox of signaling specificity. Growth Horm. IGF Res. 2002, 12, 81-83.

101. Dupont, J.; LeRoith, D. Insulin and insulin-like growth factor I receptors: Similarities and differences in signal transduction. Horm. Res. 2001, 55, 22-26.

102. Jui, H.Y.; Suzuki, Y.; Accili, D.; Taylor, S.I. Expression of a cDNA encoding the human insulin receptor-related receptor. J. Biol. Chem. 1994, 269, 22446-22452.

103. Zhang, B.; Roth, R.A. The insulin receptor-related receptor. Tissue expression, ligand binding specificity, and signaling capabilities. J. Biol. Chem. 1992, 267, 18320-18328.

104. Hirayama, I.; Tamemoto, H.; Yokota, H.; Kubo, S.K.; Wang, J.; Kuwano, H.; Nagamachi, Y.; Takeuchi, T.; Izumi, T. Insulin receptor-related receptor is expressed in pancreatic beta-cells and stimulates tyrosine phosphorylation of insulin receptor substrate-1 and -2. Diabetes 1999, 48, 1237-1244. 
105. Mathi, S.K.; Chan, J.; Watt, V.M. Insulin receptor-related receptor messenger ribonucleic acid: Quantitative distribution and localization to subpopulations of epithelial cells in stomach and kidney. Endocrinology 1995, 136, 4125-4132.

106. Deyev, I.E.; Sohet, F.; Vassilenko, K.P.; Serova, O.V.; Popova, N.V.; Zozulya, S.A.; Burova, E.B.; Houillier, P.; Rzhevsky, D.I.; Berchatova, A.A.; et al. Insulin receptor-related receptor as an extracellular alkali sensor. Cell Metab. 2011, 13, 679-689.

107. Nef, S.; Verma-Kurvari, S.; Merenmies, J.; Vassalli, J.D.; Efstratiadis, A.; Accili, D.; Parada, L.F. Testis determination requires insulin receptor family function in mice. Nature 2003, 426, 291-295.

108. Adams, T.E.; Epa, V.C.; Garrett, T.P.; Ward, C.W. Structure and function of the type 1 insulin-like growth factor receptor. Cell. Mol. Life Sci. 2000, 57, 1050-1093.

109. Ward, C.W.; Garrett, T.P. Structural relationships between the insulin receptor and epidermal growth factor receptor families and other proteins. Curr. Opin. Drug Discov. Dev. 2004, 7 , $630-638$.

110. Hubbard, S.R. Juxtamembrane autoinhibition in receptor tyrosine kinases. Nat. Rev. Mol. Cell Biol. 2004, 5, 464-471.

111. Cheng, I.; Stram, D.O.; Penney, K.L.; Pike, M.; Le Marchand, L.; Kolonel, L.N.; Hirschhorn, J.; Altshuler, D.; Henderson, B.E.; Freedman, M.L. Common genetic variation in IGF1 and prostate cance risk in the multiethnic cohort. J. Natl. Cancer Inst. 2006, 98, 123-134.

112. Cohen, P. The twentieth centrury struggle to decipher insulin signaling. Nat. Rev. Mol. Cell Biol. 2006, 7, 867-873.

113. Taniguchi, C.M.; Emanuelli, B.; Kahn, C.R. Critical nodes in signaling pathways: Insights into insulin action. Nat. Rev. Mol. Cell Biol. 2006, 7, 85-96.

114. Zaid, H.; Antonescu, C.N.; Randhawa, V.K.; Klip, A. Insulin action on glucose transporters through molecular switches, tracks and tethers. Biochem. J. 2008, 413, 201-215.

115. Yarden, Y.; Schlessinger, J. Epidermal growth factor induces rapid, reversible aggregation of the purified epidermal growth factor receptor. Biochemistry 1987, 26, 1443-1451.

116. Boni-Schnetzler, M.; Pilch, P.F. Mechanism of epidermal growth factor receptor autophosphorylation and high-affinity binding. Proc. Natl. Acad. Sci. USA 1987, 84, 7832-7836.

117. Weiss, F.U.; Daub, H.; Ullrich, A. Novel mechanisms of RTK signal generation. Curr. Opin. Genet. Dev. 1997, 7, 80-86.

118. Canals, F. Signal transmission by epidermal growth factor receptor: Coincidence of activation and dimerization. Biochemistry 1992, 31, 4493-4501.

119. Cormack, B.P.; Valdivia, R.H.; Falkow, S. FACS-optimized mutants of the green fluorescent protein (GFP). Gene 1996, 173, 33-38.

120. Tsien, R.Y. The green fluorescent protein. Annu. Rev. Biochem. 1998, 67, 509-544.

121. Nagai, T.; Ibata, K.; Park, E.S.; Kubota, M.; Mikoshiba, K.; Miyawaki, A. A variant of yellow fluorescent protein with fast and efficient maturation for cell-biological applications. Nat. Biotechnol. 2002, 20, 87-90.

122. Knebel, A.; Rahmsdorf, H.J.; Ullrich, A.; Herrlich, P. Dephosphorylation of receptor tyrosine kinases as target of regulation by radiation, oxidants or alkylating agents. EMBO J. 1996, 15, 5314-5325. 
123. Nagy, P.; Claus, J.; Jovin, T.M.; Arndt-Jovin, D.J. Distribution of resting and ligand-bound ErbB1 and ErbB2 receptor tyrosine kinases in living cells using number and brightness analysis. Proc. Natl. Acad. Sci. USA 2010, 107, 16524-16529.

124. Sawano, A.; Takayama, S.; Matsuda, M.; Miyawaki, A. Lateral propagation of EGF signaling after local stimulation is dependent on receptor density. Dev. Cell 2002, 3, 245-257.

125. Arevalo, J.C.; Conde, B.; Hempstead, B.L.; Chao, M.V.; Martin-Zanca, D.; Perez, P. TrkA immunoglobulin-like ligand binding domains inhibit spontaneous activation of the receptor. Mol. Cell. Biol. 2000, 20, 5908-5916.

126. Ohira, K.; Shimizu, K.; Hayashi, M. TrkB dimerization during development of the prefrontal cortex of the macaque. J. Neurosci. Res. 2001, 65, 463-469.

127. Mischel, P.S.; Umbach, J.A.; Eskandari, S.; Smith, S.G.; Gundersen, C.B.; Zampighi, G.A. Nerve growth factor signals via preexisting TrkA receptor oligomers. Biophys. J. 2002, 83, 968-976.

128. Vilar, M.; Charalampopoulos, I.; Kenchappa, R.S.; Simi, A.; Karaca, E.; Reversi, A.; Choi, S.; Bothwell, M.; Mingarro, I.; Friedman, W.J.; Schiavo, G.; Bastiaens, P.I.; Verveer, P.J.; Carter, B.D.; Ibanez, C.F. Activation of the p75 neurotrophin receptor through conformational rearrangement of disulphide-linked receptor dimers. Neuron 2009, 62, 72-83.

129. Marchetti, L.; Callegari, A.; Luin, S.; Signore, G.; Viegi, A.; Beltram, F.; Cattaneo, A. Ligand signature in the membrane dynamics of single TrkA receptor molecules. J. Cell Sci. 2013, 126, $4445-4456$.

130. He, X.L.; Garcia, K.C. Structure of nerve growth factor complexed with the shared neurotrophin receptor p75. Science 2004, 304, 870-875.

131. Wehrman, T.; He, X.; Raab, B.; Dukipatti, A.; Blau, H.; Garcia, K.C. Structural and mechanistic insights into nerve growth factor interactions with the TrkA and p75 receptors. Neuron 2007, 53, $25-38$.

132. Iacaruso, M.F.; Galli, S.; Marti, M.; Villalta, J.I.; Estrin, D.A.; Jares-Erijman, E.A.; Pietrasanta, L.I. Structural model for p75(NTR)-TrkA intracellular domain interaction: A combined FRET and bioinformatics study. J. Mol. Biol. 2011, 414, 681-698.

133. Matusica, D.; Skeldal, S.; Sykes, A.M.; Palstra, N.; Sharma, A.; Coulson, E.J. An intracellular domain fragment of the $\mathrm{p} 75$ neurotrophin receptor $(\mathrm{p} 75(\mathrm{NTR}))$ enhances tropomyosin receptor kinase A (TrkA) receptor function. J. Biol. Chem. 2013, 288, 11144-11154.

134. Massague, J.; Pilch, P.F.; Czech, M.P. Electrophoretic resolution of three major insulin receptor structures with unique subunit stoichiometries. Proc. Natl. Acad. Sci. USA 1980, 77, 7137-7141.

135. Ullrich, A.; Bell, J.R.; Chen, E.Y.; Herrera, R.; Petruzzelli, L.M.; Dull, T.J.; Gray, A.; Coussens, L.; Liao, Y.C.; Tsubokawa, M.; et al. Human insulin receptor and its relationship to the tyrosine kinase family of oncogenes. Nature 1985, 313, 756-761.

136. Ebina, Y.; Ellis, L.; Jarnagin, K.; Edery, M.; Graf, L.; Clauser, E.; Ou, J.H.; Masiarz, F.; Kan, Y.W.; Goldfine, I.D.; et al. The human insulin receptor cDNA: The structural basis for hormone-activated transmembrane signaling. Cell 1985, 40, 747-58.

137. Moxham, C.P.; Duronio, V.; Jacobs, S. Insulin-like growth factor I receptor beta-subunit heterogeneity. Evidence for hybrid tetramers composed of insulin-like growth factor I and insulin receptor heterodimers. J. Biol. Chem. 1989, 264, 13238-13244. 
138. Soos, M.A.; Siddle, K. Immunological relationships between receptors for insulin and insulin-like growth factor I. Evidence for structural heterogeneity of insulin-like growth factor I receptors involving hybrids with insulin receptors. Biochem. J. 1989, 263, 553-563.

139. Federici, M.; Porzio, O.; Zucaro, L.; Giovannone, B.; Borboni, P.; Marini, M.A.; Lauro, D.; Sesti, G. Increased abundance of insulin/IGF-I hybrid receptors in adipose tissue from NIDDM patients. Mol. Cell Endocrinol. 1997, 135, 41-47.

140. Bailyes, E.M.; Nave, B.T.; Soos, M.A.; Orr, S.R.; Hayward, A.C.; Siddle, K. Insulin receptor/IGF-I receptor hybrids are widely distributed in mammalian tissues: Quantification of individual receptor species by selective immunoprecipitation and immunoblotting. Biochem. J. 1997, 327, 209-215.

141. Sandhu, M.S.; Dunger, D.B.; Giovannucci, E.L. Insulin, insulin-like growth factor-I (IGF-I), IGF binding proteins, their biologic interactions, and colorectal cancer. J. Natl. Cancer Inst. 2002, 94, 972-980.

142. Cho, H.S.; Leahy, D.J. Structure of the extracellular region of HER3 reveals an interdomain tether. Science 2002, 297, 1330-1333.

143. Ferguson, K.M.; Berger, M.B.; Mendrola, J.M.; Cho, H.S.; Leahy, D.J.; Lemmon, M.A. EGF activates its receptor by removing interactions that autoinhibit ectodomain dimerization. Moll. Cell 2003, 11, 507-517.

144. Bouyain, S.; Longo, P.A.; Li, S.; Ferguson, K.M.; Leahy, D.J. The extracellular region of ErbB4 adopts a tethered conformation in the absence of ligand. Proc. Natl. Acad. Sci. USA 2005, 102, 15024-15029.

145. Ferguson, K.M. Structure-based view of epidermal growth factor receptor regulation. Annu. Rev. Biophys. 2008, 37, 353-373.

146. Garrett, T.P.; McKern, N.M.; Lou, M.; Elleman, T.C.; Adams, T.E.; Lovrecz, G.O.; Zhu, H.J.; Walker, F.; Frenkel, M.J.; Hoyne, P.A.; et al. Crystal structure of a truncated epidermal growth factor receptor extracellular domain bound to transforming growth factor alpha. Cell 2002, 110, $763-773$.

147. Ogiso, H.; Ishitani, R.; Nureki, O.; Fukai, S.; Yamanaka, M.; Kim, J.H.; Saito, K.; Sakamoto, A.; Inoue, M.; Shirouzu, M.; et al. Crystal structure of the complex of human epidermal growth factor and receptor extracellular domains. Cell 2002, 110, 775-787.

148. Berezov, A.; Chen, J.; Liu, Q.; Zhang, H.T.; Greene, M.I.; Murali, R. Disabling receptor ensembles with rationally designed interface peptidomimetics. J. Biol. Chem. 2002, 277, 28330-28339.

149. Walker, F.; Orchard, S.G.; Jorissen, R.N.; Hall, N.E.; Zhang, H.H.; Hoyne, P.A.; Adams, T.E.; Johns, T.G.; Ward, C.; Garrett, T.P.; et al. CR1/CR2 interactions modulate the functions of the cell surface epidermal growth factor receptor. J. Biol. Chem. 2004, 279, 22387-22398.

150. Cho, H.S.; Mason, K.; Ramyar, K.X.; Stanley, A.M.; Gabelli, S.B.; Denney, D.W., Jr.; Leahy, D.J. Structure of the extracellular region of HER2 alone and in complex with the Herceptin Fab. Nature 2003, 421, 756-760.

151. Garrett, T.P.; McKern, N.M.; Lou, M.; Elleman, T.C.; Adams, T.E.; Lovrecz, G.O.; Kofler, M.; Jorissen, R.N.; Nice, E.C.; Burgess, A.W.; et al. The crystal structure of a truncated ErbB2 
ectodomain reveals an active conformation, poised to interact with other ErbB receptors. Mol. Cell 2003, 11, 495-505.

152. Jura, N.; Endres, N.F.; Engel, K.; Deindl, S.; Das, R.; Lamers, M.H.; Wemmer, D.E.; Zhang, X.; Kuriyan, J. Mechanism for activation of the EGF receptor catalytic domain by the juxtamembrane segment. Cell 2009, 137, 1293-1307.

153. Zhang, X.; Gureasko, J.; Shen, K.; Cole, P.A.; Kuriyan, J. An allosteric mechanism for activation of the kinase domain of epidermal growth factor receptor. Cell 2006, 125, 1137-1149.

154. Stamos, J.; Sliwkowski, M.X.; Eigenbrot, C. Structure of the epidermal growth factor receptor kinase domain alone and in complex with a 4-anilinoquinazoline inhibitor. J. Biol. Chem. 2002, 277, 46265-46272.

155. Huse, M.; Kuriyan, J. The conformational plasticity of protein kinases. Cell 2002, 109, 275-282.

156. Jeffrey, P.D.; Russo, A.A.; Polyak, K.; Gibbs, E.; Hurwitz, J.; Massague, J.; Pavletich, N.P. Mechanism of CDK activation revealed by the structure of a cyclinA-CDK2 complex. Nature 1995, 376, 313-320.

157. Red Brewer, M.; Choi, S.H.; Alvarado, D.; Moravcevic, K.; Pozzi, A.; Lemmon, M.A.; Carpenter, G. The juxtamembrane region of the EGF receptor functions as an activation domain. Mol. Cell 2009, 34, 641-651.

158. Jing, S.; Tapley, P.; Barbacid, M. Nerve growth factor mediates signal transduction through trk homodimer receptors. Neuron 1992, 9, 1067-1079.

159. Bothwell, M.A.; Shooter, E.M. Dissociation equilibrium constant of beta nerve growth factor. J. Biol. Chem. 1977, 252, 8532-8536.

160. McDonald, N.Q.; Lapatto, R.; Murray-Rust, J.; Gunning, J.; Wlodawer, A.; Blundell, T.L. New protein fold revealed by a $2.3-\AA \AA$ resolution crystal structure of nerve growth factor. Nature 1991, 354, 411-414.

161. Radziejewski, C.; Robinson, R.C.; DiStefano, P.S.; Taylor, J.W. Dimeric structure and conformational stability of brain-derived neurotrophic factor and neurotrophin-3. Biochemistry 1992, 31, 4431-4436.

162. Ibanez, C.F.; Ilag, L.L.; Murray-Rust, J.; Persson, H. An extended surface of binding to Trk tyrosine kinase receptors in NGF and BDNF allows the engineering of a multifunctional pan-neurotrophin. EMBO J. 1993, 12, 2281-2293.

163. Artim, S.C.; Mendrola, J.M.; Lemmon, M.A. Assessing the range of kinase autoinhibition mechanisms in the insulin receptor family. Biochem. J. 2012, 448, 213-220.

164. Vilar, M.; Charalampopoulos, I.; Kenchappa, R.S.; Reversi, A.; Klos-Applequist, J.M.; Karaca, E.; Simi, A.; Spuch, C.; Choi, S.; Friedman, W.J.; et al. Ligand-independent signaling by disulfide-crosslinked dimers of the p75 neurotrophin receptor. J. Cell Sci. 2009, 122, 3351-3357.

165. Li, S.; Covino, N.D.; Stein, E.G.; Till, J.H.; Hubbard, S.R. Structural and biochemical evidence for an autoinhibitory role for tyrosine 984 in the juxtamembrane region of the insulin receptor. J. Biol. Chem. 2003, 278, 26007-26014.

166. Hubbard, S.R. The insulin receptor: Both a prototypical and atypical receptor tyrosine kinase. Cold Spring Harb. Perspect. Biol. 2013, 5, a008946.

167. Hubbard, S.R.; Wei, L.; Ellis, L.; Hendrickson, W.A. Crystal structure of the tyrosine kinase domain of the human insulin receptor. Nature 1994, 372, 746-754. 
168. Munshi, S.; Kornienko, M.; Hall, D.L.; Reid, J.C.; Waxman, L.; Stirdivant, S.M.; Darke, P.L.; Kuo, L.C. Crystal structure of the Apo, unactivated insulin-like growth factor-1 receptor kinase. Implication for inhibitor specificity. J. Biol. Chem. 2002, 277, 38797-38802.

169. Menting, J.G.; Whittaker, J.; Margetts, M.B.; Whittaker, L.J.; Kong, G.K.; Smith, B.J.; Watson, C.J.; Zakova, L.; Kletvikova, E.; Jiracek, J.; et al. How insulin engages its primary binding site on the insulin receptor. Nature 2013, 493, 241-245.

170. Schlessinger, J. Allosteric regulation of the epidermal growth factor receptor kinase. J. Cell Biol. 1986, 103, 2067-2072.

171. Macdonald, J.L.; Pike, L.J. Heterogeneity in EGF-binding affinities arises from negative cooperativity in an aggregating system. Proc. Natl. Acad. Sci. USA 2008, 105, 112-117.

172. Macdonald-Obermann, J.L.; Pike, L.J. The intracellular juxtamembrane domain of the epidermal growth factor (EGF) receptor is responsible for the allosteric regulation of EGF binding. J. Biol. Chem. 2009, 284, 13570-13576.

173. De Meyts, P.; Roth, J.; Neville, D.M., Jr.; Gavin, J.R., III; Lesniak, M.A. Insulin interactions with its receptors: Experimental evidence for negative cooperativity. Biochem. Biophys. Res. Commun. 1973, 55, 154-161.

174. Shoyab, M.; De Larco, J.E.; Todaro, G.J. Biologically active phorbol esters specifically alter affinity of epidermal growth factor membrane receptors. Nature 1979, 279, 387-391.

175. Magun, B.E.; Matrisian, L.M.; Bowden, G.T. Epidermal growth factor. Ability of tumor promoter to alter its degradation, receptor affinity and receptor number. J. Biol. Chem. 1980, 255, 6373-6381.

176. King, A.C.; Cuatrecasas, P. Resolution of high and low affinity epidermal growth factor receptors. Inhibition of high affinity component by low temperature, cycloheximide, and phorbol esters. J. Biol. Chem. 1982, 257, 3053-3060.

177. Kawamoto, T.; Sato, J.D.; Le, A.; Polikoff, J.; Sato, G.H.; Mendelsohn, J. Growth stimulation of A431 cells by epidermal growth factor: Identification of high-affinity receptors for epidermal growth factor by an anti-receptor monoclonal antibody. Proc. Natl. Acad. Sci. USA 1983, 80, 1337-1341.

178. Defize, L.H.; Boonstra, J.; Meisenhelder, J.; Kruijer, W.; Tertoolen, L.G.; Tilly, B.C.; Hunter, T.; van Bergen en Henegouwen, P.M.; Moolenaar, W.H.; de Laat, S.W. Signal transduction by epidermal growth factor occurs through the subclass of high affinity receptors. J. Cell Biol. 1989, 109, 2495-2507.

179. Bellot, F.; Moolenaar, W.; Kris, R.; Mirakhur, B.; Verlaan, I.; Ullrich, A.; Schlessinger, J.; Felder, S. High-affinity epidermal growth factor binding is specifically reduced by a monoclonal antibody, and appears necessary for early responses. J. Cell Biol. 1990, 110, 491-502.

180. Hunter, T.; Ling, N.; Cooper, J.A. Protein kinase C phosphorylation of the EGF receptor at a threonine residue close to the cytoplasmic face of the plasma membrane. Nature 1984, 311, 480-483.

181. Özcan, F.; Klein, P.; Lemmon, M.A.; Lax, I.; Schlessinger, J. On the nature of low- and high-affinity EGF receptors on living cells. Proc. Natl. Acad. Sci. USA 2006, 103, 5735-5740. 
182. Livneh, E.; Prywes, R.; Kashles, O.; Reiss, N.; Sasson, I.; Mory, Y.; Ullrich, A.; Schlessinger, J. Reconstitution of human epidermal growth factor receptors and its deletion mutants in cultured hamster cells. J. Biol. Chem. 1986, 261, 12490-12497.

183. Wofsy, C.; Goldstein, B.; Lund, K.; Wiley, H.S. Implications of epidermal growth factor (EGF) induced egf receptor aggregation. Biophys. J. 1992, 63, 98-110.

184. Lemmon, M.A.; Bu, Z.; Ladbury, J.E.; Zhou, M.; Pinchasi, D.; Lax, I.; Engelman, D.M.; Schlessinger, J. Two EGF molecules contribute additively to stabilization of the EGFR dimer. EMBO J. 1997, 16, 281-294.

185. Klein, P.; Mattoon, D.; Lemmon, M.A.; Schlessinger, J. A structure-based model for ligand binding and dimerization of EGF receptors. Proc. Natl. Acad. Sci. USA 2004, 101, 929-934.

186. Holbrook, M.R.; Slakey, L.L.; Gross, D.J. Thermodynamic mixing of molecular states of the epidermal growth factor receptor modulates macroscopic ligand binding affinity. Biochem. J. 2000, 352, 99-108.

187. Mayawala, K.; Vlachos, D.G.; Edwards, J.S. Heterogeneities in EGF receptor density at the cell surface can lead to concave up scatchard plot of EGF binding. FEBS Lett. 2005, 579, 3043-3047.

188. Alvarado, D.; Klein, D.E.; Lemmon, M.A. Structural basis for negative cooperativity in growth factor binding to an EGF receptor. Cell 2010, 142, 568-579.

189. Liu, P.; Cleveland, T.E., 4th; Bouyain, S.; Byrne, P.O.; Longo, P.A.; Leahy, D.J. A single ligand is sufficient to activate EGFR dimers. Proc. Natl. Acad. Sci. USA 2012, 109, 10861-10866.

190. Sako, Y.; Minoghchi, S.; Yanagida, T. Single-molecule imaging of EGFR signalling on the surface of living cells. Nat. Cell Biol. 2000, 2, 168-172.

191. Lu, C.; Mi, L.Z.; Schurpf, T.; Walz, T.; Springer, T.A. Mechanisms for kinase-mediated dimerization of the epidermal growth factor receptor. J. Biol. Chem. 2012, 287, 38244-38253.

192. Adak, S.; DeAndrade, D.; Pike, L.J. The tethering arm of the EGF receptor is required for negative cooperativity and signal transduction. J. Biol. Chem. 2011, 286, 1545-1555.

193. Adak, S.; Yang, K.S.; Macdonald-Obermann, J.; Pike, L.J. The membrane-proximal intracellular domain of the epidermal growth factor receptor underlies negative cooperativity in ligand binding. J. Biol. Chem. 2011, 286, 45146-45155.

194. Downward, J.; Waterfield, M.D.; Parker, P.J. Autophosphorylation and protein kinase C phosphorylation of the epidermal growth factor receptor. Effect on tyrosine kinase activity and ligand binding affinity. J. Biol. Chem. 1985, 260, 14538-14546.

195. Mahadeo, D.; Kaplan, L.; Chao, M.V.; Hempstead, B.L. High affinity nerve growth factor binding displays a faster rate of association than p140trk binding. Implications for multi-subunit polypeptide receptors. J. Biol. Chem. 1994, 269, 6884-6891.

196. Bothwell, M. Keeping track of neurotrophin receptors. Cell 1991, 65, 915-918.

197. Chao, M.V. Neurotrophin receptors: A window into neuronal differentiation. Neuron 1992, 9 , 583-593.

198. Vesa, J.; Kruttgen, A.; Shooter, E.M. p75 reduces TrkB tyrosine autophosphorylation in response to brain-derived neurotrophic factor and neurotrophin 4/5. J. Biol. Chem. 2000, 275, 24414-24420.

199. Barker, P.A. High affinity not in the vicinity? Neuron 2007, 53, 1-4. 
200. Esposito, D.; Patel, P.; Stephens, R.M.; Perez, P.; Chao, M.V.; Kaplan, D.R.; Hempstead, B.L. The cytoplasmic and transmembrane domains of the p75 and Trk A receptors regulate high affinity binding to nerve growth factor. J. Biol. Chem. 2001, 276, 32687-32695.

201. Frattali, A.L.; Treadway, J.L.; Pessin, J.E. Transmembrane signaling by the human insulin receptor kinase. Relationship between intramolecular beta subunit trans- and cis-autophosphorylation and substrate kinase activation. J. Biol. Chem. 1992, 267, 19521-19528.

202. De Meyts, P.; Whittaker, J. Structural biology of insulin and IGF1 receptors: Implication for drug design. Nat. Rev. Drug Discov. 2002, 1, 769-783.

203. De Meyts, P. The structural basis of insulin and insulin-like growth factor-I receptor binding and negative co-operativity, and its relevance to mitogenic versus metabolic signaling. Diabetologia 1994, 37, S135-S148.

204. De Meyts, P. The insulin receptor: A prototype for dimeric, allosteric membrane receptors? Trends Biochem. Sci. 2008, 33, 376-384.

205. Kiselyov, V.V.; Versteyhe, S.; Gauguin, L.; De Meyts, P. Harmonic oscillator model of the insulin and IGF1 receptors' allosteric binding and activation. Mol. Syst. Biol. 2009, 5, 243.

206. Knudsen, L.; De Meyts, P.; Kiselyov, V.V. Insight into the molecular basis for the kinetic differences between the two insulin receptor isoforms. Biochem. J. 2011, 440, 397-403.

207. Boni-Schnetzler, M.; Scott, W.; Waugh, S.M.; DiBella, E.; Pilch, P.F. The insulin receptor. Structural basis for high affinity ligand binding. J. Biol. Chem. 1987, 262, 8395-401.

208. Sweet, L.J.; Morrison, B.D.; Pessin, J.E. Isolation of functional alpha beta heterodimers from the purified human placental alpha 2 beta 2 heterotetrameric insulin receptor complex. A structural basis for insulin binding. J. Biol. Chem. 1987, 262, 6939-6942.

209. Pang, D.T.; Shafer, J.A. Stoichiometry for the binding of insulin to insulin receptors in adipocyte membranes. J. Biol. Chem. 1983, 258, 2514-2518.

210. Pang, D.T.; Shafer, J.A. Evidence that insulin receptor from human placenta has a high affinity for only one molecule of insulin. J. Biol. Chem. 1984, 259, 8589-8596.

211. Hoyne, P.A.; Elleman, T.C.; Adams, T.E.; Richards, K.M.; Ward, C.W. Properties of an insulin receptor with an IGF-1 receptor loop exchange in the cysteine-rich region. FEBS Lett. 2000, 469, 57-60.

212. Marsh, J.W.; Westley, J.; Steiner, D.F. Insulin-receptor interactions. Presence of a positive cooperative effect. J. Biol. Chem. 1984, 259, 6641-6649.

213. Riedel, H.; Dull, T.J.; Schlessinger, J.; Ullrich, A. A chimaeric receptor allows insulin to stimulate tyrosine kinase activity of epidermal growth factor receptor. Nature 1986, 324, 68-70.

(C) 2014 by the authors; licensee MDPI, Basel, Switzerland. This article is an open access article distributed under the terms and conditions of the Creative Commons Attribution license (http://creativecommons.org/licenses/by/3.0/). 